\title{
Monoclonal Antibody M30
}

National Cancer Institute

\section{Source}

National Cancer Institute. Monoclonal Antibody M30. NCI Thesaurus. Code C126895.

A mouse monoclonal antibody that recognizes the soluble caspase-cleaved (cc) form of human keratin, type I cytoskeletal 18 (cytokeratin 18, K18, KRT18, CK18). Monoclonal antibody M30 binds to a neo-epitope (NE) exposed after caspase cleavage after the aspartic acid residue at position 396 of K18 (K18Asp396). This neo-epitope results from the proteolytic activity of caspase-3,-7 or -9, which are active during apoptosis. Thus, M30 can be used to indirectly identify caspase activation and to determine if the cell death in a sample is due to apoptosis rather than necrosis. 